\title{
Engraftment of human adipose derived stem cells delivered in a hyaluronic acid preparation in mice ${ }^{1}$
}

\author{
Implante de células tronco do tecido adiposo humano numa preparação de ácido hialurônico em \\ camundongos
}

\begin{abstract}
Isa Dietrich", Olivia Cochet ${ }^{\mathrm{II}}$, Phi Villageois ${ }^{\mathrm{III}}$, Consuelo Junqueira Rodrigues ${ }^{\mathrm{IV}}$
IPhD, Volunteer Faculty, Department of Surgery, Laboratory of Surgical Anatomy of Human Structural Topography, School of Medicine, Sao Paulo University (USP), Brazil. Conceived and carried out the experiments, acquired and analyzed data, manuscript writing. The article is part of $\mathrm{PhD}$ degree thesis. Tutor: Consuelo Junqueira Rodrigues. IIFellow Master degree, Institute of Developmental Biology and Cancer, Centre National de la Recherche Scientifique (CNRS), University of Nice Sophia-Antipolis, France. Contributed with animals experiments and cells culture.

II'Bachelor of Science in Biology, Institute of Developmental Biology and Cancer, Centre National de la Recherche Scientifique (CNRS), University of Nice Sophia-Antipolis, France. Performed polimerase chain reaction (PCR) experiments and analysis.

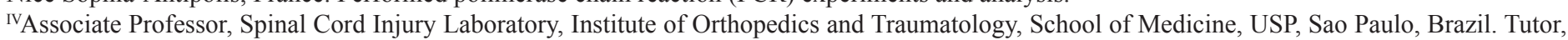
conception, design, intellectual and scientific content of the study, critical revision.
\end{abstract}

\begin{abstract}
PURPOSE: To evaluate the implant of human adipose derived stem cells (ADSC) delivered in hyaluronic acid gel (HA), injected in the subcutaneous of athymic mice.

METHODS: Control implants -HA plus culture media was injected in the subcutaneous of the left sub scapular area of 12 athymic mice. ADSC implants: HA plus ADSC suspended in culture media was injected in the subcutaneous, at the contra lateral area, of the same animals. With eight weeks, animals were sacrificed and the recovered implants were processed for extraction of genomic DNA, and histological study by hematoxilin-eosin staining and immunufluorescence using anti human vimentin and anti von Willebrand factor antibodies.
\end{abstract}

RESULTS: Controls: Not visualized at the injection site. An amorphous substance was observed in hematoxilin-eosin stained sections. Human vimentin and anti von Willebrand factor were not detected. No human DNA was detected. ADSC implants - A plug was visible at the site of injection. Fusiform cells were observed in sections stained by hematoxilin- eosin and both human vimentin and anti von Willebrand factor were detected by immunofluorescence. The presence of human DNA was confirmed.

CONCLUSION: The delivery of human adipose derived stem cells in preparations of hyaluronic acid assured cells engraftment at the site of injection.

Key words: Adult Stem Cells. Tissue Engineering. Cell Transplantation. Adipose Tissue. Hyaluronic Acid. Biocompatible Materials. Mice.

\section{RESUMO}

OBJETIVO: Avaliar o implante de células tronco do tecido adiposo humano (CTTAH) em gel de ácido hialurônico (AH), injetados no tecido subcutâneo de camundongos atímicos.

MÉTODOS: Implantes controle - HA com meio de cultura foram injetados no tecido subcutâneo da região infraescapular esquerda de 12 camundongos atímicos. Implantes de CTTAH: HA com CTTAH suspensas em meio de cultura foi injetado no subcutâneo da região contra lateral, dos mesmos animais. Com oito semanas, os animais foram sacrificados e os implantes recuperados foram processados para extração de DNA genômico, estudo histológico por coloração por hematoxilina eosina e imnuoflurescência utilizando anticorpos anti vimentina humana e anti fator de von Willebrand.

RESULTADOS: Controles - implantes não visualizados no local da injeção. Uma substância amorfa foi observada nos cortes corados por hematoxilina eosina. Vimentina humana e fator anti von Willebrand não foram identificados. DNA humano não foi detectado. Implantes de CTTAH - Uma massa era visível no local da injeção. Células fusiformes foram observadas nos corte corados com hematoxilina eosina. Tanto vimentina humana quanto fator de von Willebrand foram identificados pela imunofluorescência. A presença de DNA humano foi confirmada.

CONCLUSÃO: O implante de células tronco do tecido adiposo humano em veículo de ácido hialurônico gel assegurou a manutenção das células no local do implante.

Descritores: Células-Tronco Adultas. Engenharia Tecidual. Transplante de Células. .Tecido Adiposo. Ácido Hialurônico. Materiais Biocompatíveis. Camundongos. 


\section{Introduction}

Adipose derived stem cells (ADSC) can be easily isolated from human lipoaspirate fat and are able to differentiate in other cell types like muscle, cartilage, and bone cells, as first-handed by Zuk et $a l{ }^{1,2}$. When compared to bone marrow, adipose tissue yields 100 to 1000 times more stem cells ${ }^{3-5}$.

Some clinical trials have already tested the therapeutic potential of autologous ADSC and achieved positive results in cardiac ischemia ${ }^{6}$, wound closure of irradiated areas $^{7}$ and treatment of complex fistulas in Chron's disease ${ }^{8}$.

Despite the encouraging results from early clinical studies with adult stem cells, there is no consistent evidence that autologous stem cells can survive, engraft and exerts their specific role in vivo ${ }^{9}$. Previous studies have demonstrated that to provide a scaffold, to serve as extra cellular matrix, allows cell attachment that is necessary to establish intercellular contact and signaling that ultimately leads to tissue organization ${ }^{10,11}$.

Several biocompatible materials have been investigated as potential scaffolds for ADSC like collagen, placental decellular matrix, 5, isopropylacrylamide microspheres, gelatin, poly $(\mathrm{D}, \mathrm{L}-$ lactic-co-glycolic acid), fibrin, Matrigel, and hyaluronic acid in sponges, nonwoven meshes, aminated hydrogels and copolymers, with varying results ${ }^{12,13}$.

Among them, hyaluronic acid gel (HA) has the advantage of being injectable, non-immunogenic, non-cytotoxic and approved for medical use as a filler ${ }^{14,15}$.Therefore, the possibility of delivering ADSC by a simple injection, assuring their pervasiveness at the site of injection, makes HA crosslinked gel a suitable scaffold to be tested for that purpose.

In this work we have studied the engraftment of human ADSC delivered in preparations of hyaluroinic acid gel, in the subcutaneous tissue of athymic mice.

\section{Methods}

The study was conducted in accordance with the regulations of the Ethics Committee of Nice-Sophia Antipolis University and the French Animal Protection Laws. Twelve athymic mice (Swiss nu/nu), 8-10 week-old, received intra peritoneal anesthesia with ketamin (Imalgene, Merial, $90 \mathrm{~m}$ $\mathrm{kg}$ ) and xylazin (Rompum, Bayer, $4.5 \mathrm{mg} \backslash \mathrm{kg}$ ). Under aseptic conditions, each animal was injected with the ADSC implant in the subcutaneous of the right sub scapular area and with the control implant in the subcutaneous of the left sub scapular area. We performed the injections in three different series (four animals per series) using cells from one donor in each series.

\section{Isolation and expansion of ADSC}

After informed consent, three female patients, undergoing liposuction for aesthetic reasons donated, each one, $100 \mathrm{ml}$ of lipoaspirate fat from tights. Patients were 28, 36 and 43 years old and had normal corporal mass index. The liposuction was performed by syringe aspiration system after local infiltration with a solution of adrenalin (1:200.000) and lydocain $(0.33 \%)$. The adipose tissue was processed as described by Negrel and Dani $^{16}$. Briefly, the lipoaspirate fat was washed with PBS until cleared of blood and digested in DMEM (Dulbelcco's modified Eagle medium-Gibco BRL, Gergy Pontoise, France), added with $2 \mathrm{mg} / \mathrm{ml}$ of collagenase (Boerhinger), $20 \mathrm{mg} / \mathrm{ml}$ of serum albumin fraction 5 (Sigma) and antibiotics (penicillin $124 \mu \mathrm{g} / \mathrm{ml}$, streptomycin $100 \mu \mathrm{g} / \mathrm{ml})$. Digestion was interrupted by addition of $10 \%$ of fetal calf serum (FCS) (Dutscher SA; Brumath, France) .The digested tissue was centrifuged for 5 minutes at $200 \mathrm{~g}$ and supernatant digests were discharged. The pellet was suspended and seeded in tissue culture dishes (CellStar) at the reason of $3 \times 10^{4}$ cells $/ \mathrm{cm}^{2}$ with plating media (DMEM supplemented with $10 \%$ FCS plus antibiotics). On the following day, culture dishes were washed to remove non-adherent cells and received plating media that was changed every other day. ASDC from the 2nd passage were processed for Fluorescence Activated Cell Sorting (FACS) and implanted in the animals.

\section{FACS analyses of expanded ADSC}

Expanded ADSC from each donor were processed separately as follows: cells were fixed for $30 \mathrm{~min}$ in $2 \%$ paraformaldehyde. Fixed cells were washed in flow cytometry buffer (FCB: 1X PBS; $2 \% \mathrm{FBS}$ and $0.2 \%$ Tween 20). Aliquots of 1 X $10^{6}$ cells were incubated for 30 min with FCB containing Fluorescein isothiocyanate (FITC) or R-phycoerytherin (PE) conjugated antibodies: anti CD45-FITC, CD14-PE, CD34-PE, CD13-PE, HLA-DR-FITC, CD90-PE, CD 44-FITC, CD29-FITC (Becton Dickinson), anti HLA classe1-PE, CD54-PE, e CD49e-PE, CD 51/61-FITC (Pharmingen) and anti KDR (Sigma). Anti KDR antibody was revealed by indirect immunofluorescence; cells were washed with PBS and incubated with FCB containing the secondary antibody: goat anti mouse IgG-FITC (Sigma). Isotype-matched control antibodies were used in order to accurately determine the level of specific binding. Flow cytometry was performed with a Fluorescence Activated Cell Sorting (FACS) argon laser cytometer (BDIS -Becton Dickinson Immunodiagnostic Systems) and acquired data were analyzed by Cell Quest (BDIS) program. 
Positive staining was defined as a fluorescent intensity greater than $99 \%$ of that obtained with the isotype-matched control antibody.

\section{Implants preparation}

Under aseptic conditions, $1 \times 10^{6}$ of expanded ADSC were suspended in $0.2 \mathrm{ml}$ of DMEM and mixed with $0.6 \mathrm{ml}$ of crosslinked hyaluronic acid gel (Juvederm 30). To serve as control, $0.6 \mathrm{ml}$ of the same gel was mixed with $0.2 \mathrm{ml}$ of DMEM only. Preparations were kept at $37^{\circ} \mathrm{C}$ and $5 \% \mathrm{CO} 2$, for $24 \mathrm{~h}$. On the following day, two hours before the injection in the animals, 10ng/ $\mathrm{ml}$ of basic fibroblast growth factor (bFGF) was added to controls as well to ADSC containing syringes.

\section{Recovery and analysis of implants}

Animals $(\mathrm{N}=12)$ were sacrificed by vertebral dislocation at two months of the date of the injections. Twelve pairs of implants, i.e. 12 ADSC implants and their respective controls, were recovered after the harvest of a dorsal, caudal based flap and macroscopically analyzed regarding color, consistence and vascularization. Following, implants were frozen in liquid nitrogen and kept at $-80^{\circ} \mathrm{C}$. Randomly, one pair of implants of each series was saved for DNA extraction and amplification and the remaining 3 pairs of each series were embedded in Tissue Tek OCT compound (Miles Inc., IN, USA) until sectioning in $6 \mu \mathrm{m}$ sections.

\section{Histological analysis}

Representative sections obtained from each implant were separately analyzed through light microscopic after hematoxilineoisn staining. Immunofluorescence: to identify human cells, sections were incubated with specific anti- human-vimentin mouse monoclonal antibody (V9 clone, Novo Castra Laboratories; $1: 100$ ) followed by incubation with $\operatorname{IgG}$ blocking kit (Vector MOM-mouse on mouse- Kit) to avoid unspecific binding. Finally, sections were incubated with Fluorescein-Avidin D Cell Sorter Grade (Fluorescein-Avidin DCS; Vector Laboratories). Human prepuce and mouse skin sections were processed by the same method to serve as positive and negative controls respectively. For identification of endothelial cells, representative sections of each implant were incubated with Anti mouse von Willebrand rabbit polyclonal antibody (dilution 1:100, Clotimmun, Boehring Institute) that was revealed by a secondary polyclonal swine anti rabbit - FITC conjugated antibody (dilution 1:30, Dako). Sections were mounted with 4', 6-diamidino-2-phenylindole (DAPI, Vectashield, Vector) and analyzed through a Zeiss Axiophot confocal microscope equipped with a LEICA Q55CW Cytogenetics Workstation.

\section{DNA extraction and amplification}

Four pairs of implants (one of each series) were processed for Genomic DNA extraction by TRI-REAGENT kit (Euromedex - France), following the protocol recommended by the manufacturer. The DNA extracted from each implant was separately processed by the polymerase chain reaction (PCR), to amplify a fragment of 850 -bp of the $\alpha$-satellite region of the human chromosome 17, using the following primers (Invitrogen): 5'GGATAATTTCAGCTGACTAAACAG3' and 5'TTCCGTTTAGTTAGGTGCAGTTGTTATC3'. Nucleotide position corresponds to the sequence HSSATA17 (Gen Bank No. M13882). As positive control, human cultured cells were used for extraction and amplification of the same DNA fragments .Amplified DNA fragments were submitted to electrophoresis in $2 \%$ agarose gels, stained with ethidium bromide and visualized through ultra-violet light.

\section{Results}

\section{ADSC characterization by FACS}

Cells from the second passage from each donor were separately analyzed and showed a homogeneous population regarding size and morphology. ADSC exhibited markers from stromal origin (CD90+, CD13+) and also expressed markers of interaction with metalloprotease $(\mathrm{CD} 13+)$, endothelial cells (CD29+), hyaluronic acid (CD44+), molecules of cell-to-cell adhesion (CD54+) and fibronectin (CD29+, CD49e+). Expanded ADSC did not express markers from hematopoietic lineage (CD34/- and CD45/-) and KDR. The mean percentage of positive cells for each marker is presented in Table 1, followed by a brief markers description. These results are similar to those observed by other authors ${ }^{2-5}$. 
TABLE 1 - ADSC surface markers profile.

\begin{tabular}{|c|c|c|}
\hline Surface Protein & Antigen & $\begin{array}{c}\text { Mean \% Positive Cells } \\
\text { Standard Error of Mean }\end{array}$ \\
\hline Thy-1 & CD-90 & $99.38 \pm 0.05$ \\
\hline Aminopeptidase N & CD-13 & $98.23 \pm 1.44$ \\
\hline Integrin 1 & CD-29 & $96.56 \pm 0.46$ \\
\hline Integrin 5 & CD-49e & $93.64 \pm 2.94$ \\
\hline Hyaluronate & CD-44 & $60.18 \pm 4.89$ \\
\hline MHC- class I & HLA-1 & $46.40 \pm 26.7$ \\
\hline ICAM-1 & CD-54 & $34.78 \pm 10.1$ \\
\hline alphaVbeta3 complex & CD-51/61 & $4.0 \pm 4.2$ \\
\hline PECAM & CD-34 & $3.64 \pm 3.84$ \\
\hline VEGFR-2 & KDR & $1.66 \pm 1.35$ \\
\hline MHC- class II & HLA/DR & $1.54 \pm 1.33$ \\
\hline
\end{tabular}

CD90-THY-1: cell surface glycoprotein that can be used as a marker for a variety of stem cells. CD13-Aminopeptidase N: a zinc metalloproteinase, also known as aminopeptidase N, which is found naturally on myelomonocytic cells from early differentiation through maturity. Integrins (CD29 and CD49e): integrin family members are membrane receptors involved in cell adhesion and recognition in a variety of processes including embryogenesis, homeostasis, tissue repair, immune response and metastatic diffusion of plug cells. CD44-Hyaluronate: a family of matrix adhesion molecules that adhere to hyaluronate, collagen, laminin, and fibronectin. MHC class 1-HLA class I antigens (A, B \& C): present peptides from inside the cell. (HLA human leukocyte antigen system) is the name of the major histocompatibility complex (MHC) in humans. CD54-ICAM 1: intercellular adhesion molecule. CD51/61Integrin alphaV/beta3: vitronectin receptor, high levels on osteoclasts, endothelial cells, and melanoma cells. KDR-VEGFR-2: receptor for vascular endothelial growth factor 2. HDLA-DR-MHC class II: major histocompatibility complex,class II cell surface receptor. HLA class II antigens (DP, DQ, \& DR) present antigens from outside of the cell to T-lymphocytes HLA-DR is found in macrophages, B-cells and dendritic cells. CD34-PECAM: platelet endothelial cell adhesion molecule. CD45/14-PTPRCAP: transmembrane phosphoprotein specifically associated with tyrosine phosphatase: markers of hematopoietic lineage.

\section{Macroscopic analysis}

In the dorsum of the animals, at the site of injection of ADSC implants, a plug with fibroelastic consistence, could be easily identified. At the contra lateral area, where the control implant was injected, we observed no plug (Figure 1). After harvesting the dorsal flap, the "plug" was identified as a mass of white tissue with visible vessels, while the control showed itself transparent and avascular (Figures 2a and 2b).

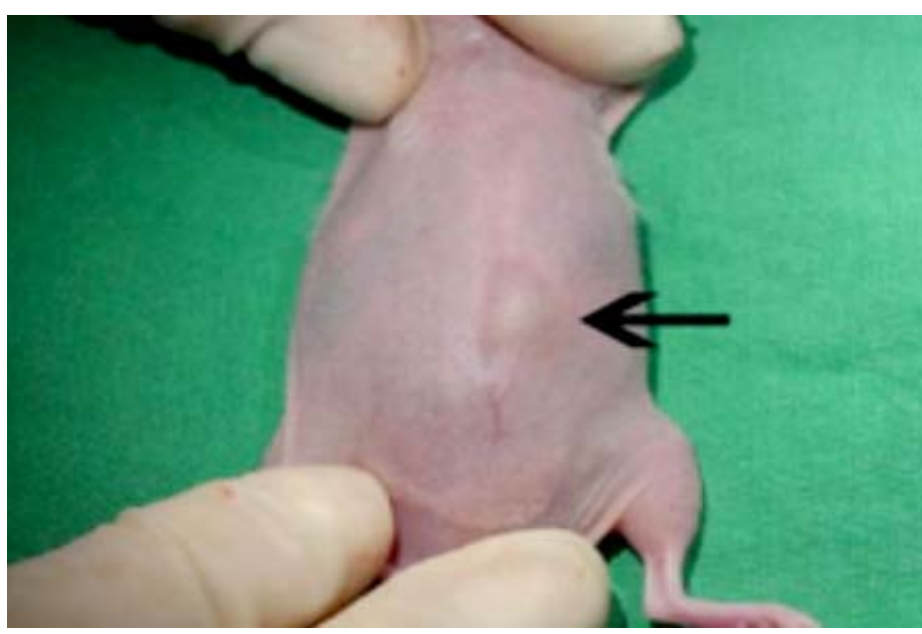

FIGURE 1 - ADSC implant in athymic mouse. Two months after the injections, arrow shows a plug corresponding to the site of injection of ADSC implant. No plug can be seen in the contra-lateral area, where the control implant was injected.

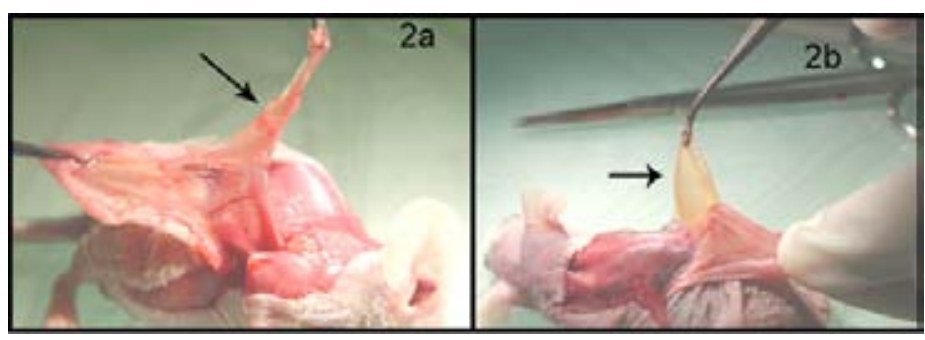

FIGURE 2 - Macroscopic observation of implants with two months of implantation. a. Arrow indicates the ADSC implant invaded by a rich vascular network. b. Arrow points the control implant, showing itself transparent and avascular.

\section{Histological analysis}

Hematoxilin-eosin staining: in ADSC implants we observed fusiform cells arranged in cord like structures. In control implants we observed just an amorphous substance occupying the implants. (Results not shown) Immunofluorescence - ADSC implants: sections incubated with specific anti-human vimentin antibody revealed an uniform distribution of vimentin filaments in all over the implants (Figure 3a). Sections incubated with anti von Willebrand antibody identified endothelial cells forming vessels (Figure 3c), in agreement with the macroscopic observation (Figure 2a). Control implants: no vimentin filaments or endothelial cells were observed (Figures $3 b$ and 3d). 


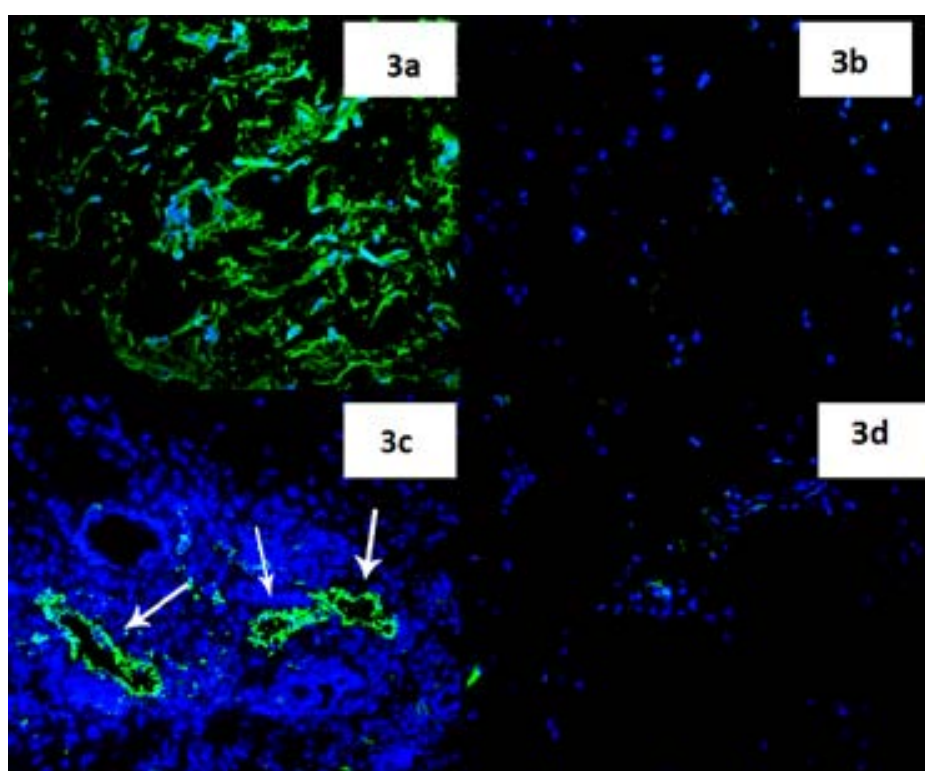

FIGURE 3 - Microscopic analysis of implants sections by immunofluorescence. a. Anti-human vimentin-FITC plus DAPI. 400X. Note the uniform distribution of human vimentin filaments inside ADSC implant. b. Anti-human vimentin-FITC plus DAPI. 400X- Note absence of human vimentin filaments in control implant. c. Anti -von Willebrand Factor-FITC plus DAPI. 200X. Observe the vessels, indicated by arrows, inside ADSC implant. d. Anti -von Willebrand Factor-FITC plus DAPI. 200X. Note the absence of vessels inside control implant.

Analysis of PCR product by electrophoresis in agarose gels

Analysis of ADSC implants DNA revealed a band correspondent to human genomic DNA that could not be identified in controls (Figure 4).

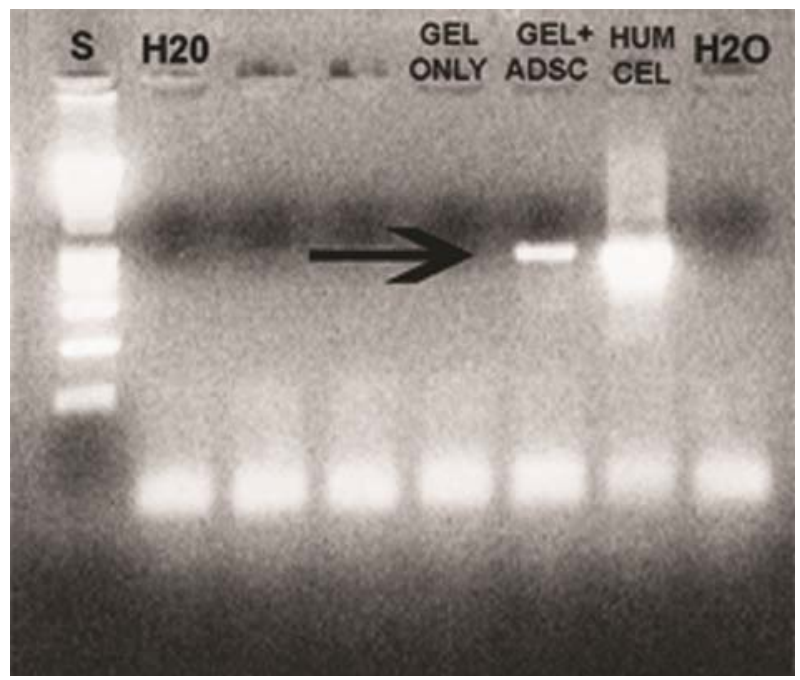

FIGURE 4 - Analysis of PCR product of ADSC implant. Arrow shows the band revealed by the electrophoresis in agarose gel of ADSC implant PCR product. Hum cell column corresponds to the positive control: amplified fragments of $850 \mathrm{pb}$ from genomic DNA extracted from cultured human cells. Gel only column corresponds to the control implant.

\section{Discussion}

To the present there are no clear evidences that cells used in cell therapy are able to engraft by themselves at the injured area where they are supposed to exert their therapeutic effect ${ }^{9,10}$. Suzuki et $a l .{ }^{17}$ injected muscular precursors cells in the healthy cardiac muscle of immune compatible mice and demonstrated that $55 \%$ of cells disappeared from muscle, 10 minutes after injection. The authors' findings suggest that the lack of homing of cells in at the area of injection may impair their potential therapeutic effect and reduce the method efficiency.

Hosting implanted cells in a biodegradable scaffold to serve as extra cellular matrix is known to regulate cell adhesion, migration and phenotype ${ }^{18-20}$. Hyaluronan or hyaluronic acid (HA) is a glycosaminoglycan that integrates the peri cellular matrix and is anchored in cells surface by CD 44, that is expressed by ADSC. Furthetmore, cross-linked HA can form cable structures and plays a key role in pushing and pulling cells in different physiological process, as observed by Evanko et al. ${ }^{14}$. Still, the biodegraditon of HA produces fragments that are angiogenic ${ }^{21-23}$. Flynn et al. ${ }^{24}$ studied implants of ADSC seeded in decellularized placenta combined with cross-linked HA, in the subcutaneous of a murine model. The authors raised the hypothesis that ADSC promoted implant vascularization by secreting chemeotatic cytokines that attracted endothelial cells. Further, according to the authors, ADSC secreted hyaluroridase that lead to release of HA fragments that also contributed to angiogenesis.

The above mentioned characteristics and properties, added to the fact that HA gel has been routinely used for cosmetic treatments ${ }^{25,26}$ makes it a suitable, readily available scaffold for delivering ADSC with therapeutic purposes, as proposed for other authors in different experimental models. Ganey et $a l^{27}$ used hyaluronic acid as a carrier for ADSC to treat intervertebral disc injury in a canine model and although they have not described the physical characteristics of the HA carrier (gel? sponge?), they reported disc regeneration. Ito et al. ${ }^{28}$, studied adipose tissue formation in athymic mice, comparing ADSC seeded in HA gel or in type I collagen sponge or non-woven polyglycolic acid. The authors concluded that although the three scaffolds served to support the cells in vivo for eight weeks, type I collagen was more efficient to promote adipocyte differentiation. Altman et $a l .^{29}$ studied implants of ADSC seeded in nonanimal stabilized hyaluronic acid in a photoaged murine model. Although their experiment was restrict to three weeks, the authors reported an organized fibrovascular network supporting the implants.

In this model we seeded ADSC in HA gel, 24h prior to the 
injection, thus providing a scaffold that assured their pervasiveness at the site of implantation. HA may have also contributed to cells viability by protecting them from oxidative damage in vitro, as demonstrated in other cell types ${ }^{30-32}$. By adding bFGF to ADSC preparations two hour before the injection, we intended to provide a signal to boost angiogenesis in the first hours after implantation, as other authors have previously suggested ${ }^{33-35}$. We hypothesize that the maintenance of the vascular network for two months in ADSC implants was due to the paracrine interaction between engrafted ADSC and host extra cellular matrix and endothelial cells, added with the pro-angiogenic effect of HA degradation.

\section{Conclusion}

In a murine model, human adipose derived stem cells, pre-seeded for $24 \mathrm{~h}$ in HA, engrafted at the site of implantation and induced the development of a vascular network that supported the implants for two months.

\section{References}

1. Zuk PA, Zhu M, Mizuno H, Huang J, Futrell JW, Katz AJ, Benhaim P, Lorenz HP, Hedrick MH. Multilineage cells from human adipose tissue: implications for cell-based therapies. Tissue Eng. 2001;7:21128.

2. Zuk PA, Zhu M, Ashjian P, De Ugarte DA, Huang JI, Mizubo $\mathrm{H}$, Alfonso CZ, Fraser JK, Benhaim P, Hedrick MH. Human adipose tissue is a source of multipotent stem cells. Mol Biol Cell. 2002;13:4279-95.

3. De Ugarte DA, Morizono K, Elbarbary A, Alfonso Z, Zuk PA, Zhu M, Dragoo JL, Ashjian P, Thomas B, Benhaim P, Chen I, Fraser J, Hedrick MH. Comparison of multi-lineage cells from human adipose tissue and bone marrow. Cells Tissues Organs. 2003;174:101-9.

4. De Ugarte DA, Ashjian PH, Elbarbary A, Hedrick MH. Future of fat as raw material for tissue regeneration. Ann Plast Surg. 2003;50:2159.

5. Fraser JK. Adipose tissue: challenging the marrow monopoly. Cytotherapy. 2002;4(6):509-10.

6. Schenke-Layland K, Strem BM, Jordan MC, Deemedio MT, Hedrick MH, Roos KP, Fraser JK, Maclellan WR. Adipose tissue-derived cells improve cardiac function following myocardial infarction. J Surg Res. 2009;153(2):217-23.

7. Rigotti G, Marchi A, Galie M Baroni G, Benati G, Krampera M, Pasini A, Sbarbati A. Clinical treatment of radiotherapy tissue damage by lipoaspirate transplant: a healing process mediated by adiposederived adult stem cells. Plast Reconstr Surg. 2007;119(5):1409-22.

8. Garcia-Olmo D, Herreros D, Pascual I, Pascual JA, Del-Valle , Zorrilla J, De-La-Quintana P, Garcia-Arranz M, Pascual M. Expanded ADSC for the treatment of complex perianal fistula: a phase II clinical trial. Dis Colon Rectum. 2009;52(1):79-86.

9. Weissberg PL, Qasim A. Stem cell therapy for myocardial repair. Heart. 2005;91(5):696-702.

10. Senoo H, Imai K, Matano Y, Sato M. Molecular mechanisms in the reversible regulation of morphology, proliferation and collagen metabolism in hepatic stellate cells by the three-dimensional structure of the extracellular matrix. J Gastroenterol Hepatol.
1998;13 Suppl:S19-32.

11. Vacanti CA, Vacanti JP. The science of tissue engineering. Orthop Clin North Am. 2000;31(3):351-6.

12. Pachence JM, Kohn J. Biodegradable materials. In Lanza PR, Langer R, Vacanti J. Principles of tissue engineering. 2ed. San Diego: Academic Press; 2000. p.269-77.

13. Chan BP, Leong KW. Scaffolding in tissue engineering: general approaches and tissue-specific considerations. Eur Spine J. 2008;17 467-79.

14. Evanko SP,Tammi MI, Tammi RH, WightTN. Hyaluronan-dependent pericellular matrix. Adv Drug Deliv Rev. 2000;59(13):1351-65.

15. Pardue EL, Ibrahim S, Ramamurthi A. Role of hyaluronan in angiogenesis and its utility to angiogenic tissue engineering. Organogenesis. 2008;4(4):203-14.

16. Negrel R, Dani C. Cultures of adipose precursor cells and cells of clonal lines from animal white adipose tissue. Methods Mol Biol. 2001;155:225-37.

17. Suzuki K, Murtuza B, Beauchamp JR, Brand NJ, Barton PJ, Carver A, Fukushima S, Coppen SR, Partridge TA, Yacoub MH Varela. Role of interleukin-1beta in acute inflammation and graft death after cell transplantation to the heart. Circulation. 2004;14:219-24.

18. Varzaneh FE, Shillabeer G, Wong KL, Lau DC. Extracellular matrix components secreted by microvascular endothelial cells stimulate preadipocyte differentiation in vitro. Metabolism. 1994;43(7):90612.

19. Hausman DB, DiGirolamo M, Bartness TJ, Hausman GJ, Martin RJ. The biology of white adipocyte proliferation. Obes Rev. 2001;2(4):239-54.

20. Senoo H, Imai K, Matano Y, Sato M. Molecular mechanisms in the reversible regulation of morphology, proliferation and collagen metabolism in hepatic stellate cells by the three-dimensional structure of the extracellular matrix. J Gastroenterol Hepatol. 1998;13:19-32.

21. Pardue EL, Ibrahim S, Ramamurthi A. Role of hyaluronan in angiogenesis and its utility to angiogenic tissue engineering. Organogenesis. 2008;4(4):203-14.

22. Fournier N, Doillon CJ. Biological molecule-impregnated polyester: an in vivo angiogenesis study. Biomaterials. 1996;17:1659-65.

23. Montesano R, Kumar S, Orci L, Pepper MS. Synergistic effect of hyaluronan oligosaccharides and vascular endothelial growth factor on angiogenesis in vitro. Lab Invest. 1996;75:249-62.

24. Flynn L, Prestwich GD, Semple JL, Woodhouse KA. Adipose tissue engineering in vivo with adipose-derived stem cells on naturally derived scaffolds. J Biomed Mater Res A 2009;89(4):929-41.

25. Sclafani AP, Romo $T$ 3rd. Injectable fillers for facial soft tissue enhancement. Facial Plast Surg. 2000;16(1):29-34.

26. Allemann IB, Baumann L. Hyaluronic acid gel (Juvéderm ${ }^{\mathrm{TM}}$ ) preparations in the treatment of facial wrinkles and folds. Clin Interv Aging. 2008;3(4):629-34.

27. Ganey T, Hutton WC, Moseley T, Hedrick M, Meisel HJ. Intervertebral disc repair using adipose tissue-derived stem and regenerative cells: experiments in a canine model. Spine. 2009;34(21):2297-304.

28. Itoi Y, Takatori M, Hyakusoku H, Mizuno H. Comparison of readily available scaffolds for adipose tissue engineering using adiposederived stem cells. J Plast Reconstr Aesthet Surg. 2010;63:858-64.

29. Altman AM, Abdul Khalek FJ, Seidensticker M, Pinilla S, Yan Y, Coleman M, Song YH, Butler CE, Alt EU. Hman tissue-resident stem cells combined with hyaluronic acid gel provide fibrovascularintegrated soft-tissue augmentation in a murine photoaged skin model. Plast Reconstr Surg. 2010;125(1):63-73.

30. Campo GM, D'Ascola A, Avenoso A, Campo S, Ferlazzo AM, Micali C, Zanghi L, Calatroni A. Glycosaminoglycans reduce 
oxidative damage induced by copper $(\mathrm{Cu}+2)$, iron $(\mathrm{Fe}+2)$ and hydrogen peroxide (H2O2) in human fibroblast cultures. Glycoconj J 2004;20(2):133-41.

31. Halicka HD, Mitlitski V, Heeter J, Balazs EA, Darzynkiewicz Z Attenuation of the oxidative burst-induced DNA damage in human leukocytes by hyaluronan. Int J Mol Med. 2009;23(5):695-9.

32. Pauloin T, Dutot M, Joly F, Warnet JM, Rat P. High molecular weight hyaluronan decreases UVB-induced apoptosis and inflammation in human epithelial corneal cells. Mol Vis. 2009;15:577-83.

33. Pepper MS, Mandriota SJ, Jeltsch M, Kumar V, Alitalo K. Vascular endothelial growth factor (VEGF)-C synergizes with basic fibroblast growth factor and VEGF in the induction of angiogenesis in vitro and alters endothelial cell extracellular proteolytic activity. J Cell Physiol. 1998;177(3):439-52.

34. Mandriota SJ, Pepper MS. Vascular endothelial growth factorinduced in vitro angiogenesis and plasminogen activator expression are dependent on endogenous basic fibroblast growth factor. J Cell Sci. 1999;110:2293-302.

35. Kawaguchi N, Toriyama K, Nicodemou-Lena E, Inou K, Torii S, Kitagawa Y. De novo adipogenesis in mice at the site of injection of basement membrane and basic fibroblast growth factor. Proc Natl Acad Sci USA. 1998;95(3):1062-6.

\section{Acknowledgements}

The authors are most grateful to Doctor Christian Dani for both his continuous advice and guidance during the experiments conducted at the Laboratory of the Institute of Developmental Biology and Cancer, UMR6543 of Nice-Sophia Antipolis University. Anne Spadafora for technical assistance with immunofluorescence analysis and Prof. Gerard Ailhaud for his continuous support.

\section{Correspondence:}

Isa Dietrich

Avenida Dr. Arnaldo, 455/1302

01246903 São Paulo - SP Brasil

Tel./Fax: (55 11)3061-8277

isa.dietrich@isa.med.br

Received: November 14, 2011

Review: January 12, 2012

Accepted: February 15, 2012

Conflict of interest: none

Financial source: Co-ordination of Improvement for Higher Academic Staff (CAPES)

${ }^{1}$ Research performed at the Laboratory of the Institute of Developmental Biology and Cancer, Unité Mixte de Recherche (UMR) 6543, Centre National de la Recherche Scientifique (CNRS), University of Nice Sophia-Antipolis, France. 